DOI: $\underline{10.35619 / \text { iiu.v1i14.398 }}$

Палько Тетяна

кандидат психологічних наук, доцент кафедри педагогіки та психології Закарпатського інституту післядипломної педагогічної освіти,

м. Ужгород, Україна

ORCID: 0000-0003-2273-1472

e-mail: tanya0106.1967@ukr.net

\title{
РЕАЛІЗАЦІЯ АВТОРСЬКОЇ ПЕДАГОГІЧНОЇ СИСТЕМИ В. СУХОМЛИНСЬКОГО В ОСВІТНЬОМУ ПРОЦЕСІ ПРИРОДНОГО СЕРЕДОВИЩА ЗАКАРПАТТЯ
}

Анотація. У статті представлено дослідження авторської педагогічної системи Василя Сухомлинського, охарактеризовано форми освітньої діяльності «під блакитним небом». Окреслено фактори удосконалення професіоналізму вчителя, які, на переконання В. Сухомлинського, розкривають творчий потенціал вчителя $\mathrm{i}$ визначають сенс його професіоналізму впродовж життя: наявність у нього віри в дитину; поєднання емоційної культури 3 тактом; дотримання вчителем інтелектуальної культури; орієнтація учнів на особистий приклад вчителя; поглиблення, поповнення, удосконалення знань; самоаналіз педагогічної праці; іiі дослідницький, творчий характер, використання передового педагогічного досвіду; атмосфера багатого духовного життя колективу.

Великий педагог довів, що природа сама собою не виховує, виховує лише активна взаємодія дитини 3 нею. Тому екологічне виховання та екологічна культура тісно пов'язані 3 природоохоронною діяльністю. В. Сухомлинський вважав, що самих екологічних знань 3 охорони навколишнього середовища, якщо вони не втілюються на практиці, недостатньо. Важливо, щоб вихованці брали участь у збереженні і збагаченні природи рідного краю, тільки у цьому разі у них формуються необхідні уміння і навички, розвивається відповідальне, бережне ставлення до навколишнього середовища.

Ключові слова: авторська педагогічна система, «Школа під блакитним небом», Павлиська школа, фасилітатор, модератор, коуч.

Постановка проблеми. Процеси глобалізації, технічного прогресу, зростання соціальної конкуренції зумовлюють необхідність пошуку педагогом нових форм і методів мотивації здобувачів освіти до критичного мислення, уникнення стереотипних способів вирішення проблем, прийняття нестандартних рішень та використання своїх знань і навичок на практиці. У сучасній школі існуючі методи не повною мірою забезпечують наведені вище завдання. Упровадження в роботу сучасних закладів освіти 


\section{Інноватика у вихованні. Випуск 14. 2021.}

позитивного досвіду минулих поколінь може вирішити цю проблему. Питання розвитку дитячої особистості за допомогою природи знайшли своє відображення у педагогічній системі В. Сухомлинського. Видатний педагог розглядав природу на основі системного наукового підходу, визначаючи багатогранність їі впливу на особистість дитини, необхідність використання природи як засобу формування особистості ще з раннього дитинства. В. Сухомлинський любив повторювати: «Тут, у природі, вічне джерело дитячого розуму» (Литвин 2013, с. 33). Але навчити дітей бачити прекрасне у звичайних речах - справа нелегка. Якщо педагог сам любить природу та бережно до неї ставиться, то він з легкістю зможе передати це дітям. В. Сухомлинський вказував, що «Найкраща, найтонша методика $є$ лише тоді, коли є жива індивідуальність педагога, коли в загальне він вносить щось своє, глибоко продумане» (Литвин, 2013, с. 29).

Мета статті - провести дослідження авторської педагогічної системи Василя Сухомлинського, окресливши фактори удосконалення професіоналізму вчителя. Розкрити значення педагогічної спадщини В. Сухомлинського з метою її реалізації в освітньому процесі природного середовища Закарпаття.

Аналіз останніх досліджень 3 проблеми. Різноманітні аспекти психолого-педагогічної науки, висвітлені у працях В. Сухомлинського, вивчали Г. Александров, К. Баханов, В. Беспалько, І. Бех, М. Головко, Н. Гупан, Н. Дічек, Н. Кузьміна, М. Марусинець, Л. Новикова, I. Прокопенко, О. Савченко, С. Салтанов, О. Сухомлинська та ін. Також сучасні дослідники педагогічної майстерності В. О. Сухомлинського доводять перспективність екологічного виховання. Це відображено у працях педагогів дослідників, вчених Л. Бондар, Г. Василенко, О. Вознюк, T. Гладюк, I. Жаркової, Н. Калініченко, О. Савченко, А. Степанюк, Л. Руденко та багатьох інших. Досліджуючи спадщину екологічного виховання В. О. Сухомлинського, вчені констатують, що метою екологічного виховання великого педагога було цілеспрямоване формування у його вихованців міцних екологічних знань, розуміння та єдності людини з природним середовищем як єдиної гармонії, виховання особливої відповідальності за стан навколишнього середовища. Саме 3 раннього дитинства варто виховувати в дітях екологічний світогляд. Досліджуючи «Книгу природи» В. Сухомлинського, вони доводять, що кожна сторінка виховує, надихає, вчить доброті і чуйності.

Ідеї В. Сухомлинського знайшли своє продовження у працях таких зарубіжних науковців, як-от: М. Библюк (Польша), М. Богуславський, I. Валеєва, Г. Волкова, М. Мухіна, Л. Федорової (Росія), Е. Гартман, У. Грош, В. Гюнтер, В. Іфферт, Р. Штайник (Німеччина), М. Дмитрієва, Т. Когачевської (Білорусь), Дж. Зайди, А. Кокерілля (Австралія), Ван Ігао, Сао Су, Бі Шуджі, Тан Чіці (Китай), Д. Маргуліса (США), Л. Мілкова (Болгарія), Х. Франгоса (Греція).

Виклад основного матеріалу дослідження. Василь Сухомлинський створив авторську педагогічну систему, яка має гуманістичний характер, 


\section{Інноватика у вихованні. Випуск 14. 2021.}

що проявляється в орієнтації на досягнення успіху та спільну діяльність. Її основою $є$ сукупність елементів педагогічного процесу, які відображають засоби, методи, форми та прийоми досягнення поставленої мети.

Уперше Василь Сухомлинський використав поняття «педагогічна система» стосовно своєї діяльності у статті «Моя педагогічна система». Він визначив сутність власної педагогічної системи, розкрив основні принципи та охарактеризував піi складові компоненти. Учений вважав, що «педагогічна система - це втілення положень і узагальнень педагогічної теорії в конкретних стосунках педагога з вихованцями, в повсякденному їх спілкуванні в найрізноманітніших сферах духовного життя, активної діяльності» (Сухомлинський, 1988, с.86-91).

Характеризуючи власну педагогічну систему, педагог включав до неї всю багатогранність, сукупність методів і прийомів виховного впливу особи педагога на колектив і особу вихованця з метою виховання всебічно, гармонійно розвиненої особистості, стверджуючи, що вона грунтується на системі поглядів і переконань учителя і не $є$ механічним повторенням педагогічної теорії, а містить щось глибоко індивідуальне.

Характерною ознакою індивідуального професійного часу Василя Сухомлинського є те, що він не співпадає з сучасним хронотопом у тому сенсі, що відтворення педагога-професіонала тотально відбувалося лише у межах існуючої політичної й науково-фахової ідеології. Згідно 3 нею встановлювалися жорсткі вимоги не лише до змісту суспільно заданого навчання, а й нормативного обсягу його форм і методів. Великий педагог на своїй тривалій практиці усвідомлював недостатність такої загальної ідейно-освітньої настанови. Для цього треба було мати відповідну мужність, щоб усвідомити подібний стан речей, а по-друге, сформувати інше професійне бачення i, що головне, спробувати реалізувати його спочатку частково, а далі - стосовно всього освітнього закладу, тобто Павлишської школи.

Педагогічний процес Павлишської середньої школи базувався на повсякденному спілкуванні вчителя 3 учнем під час класно-урочної і позакласної роботи. 22 роки життя Василь Олександрович очолював цей заклад освіти i проводив у ньому довготривалий педагогічний експеримент, результатом якого стало створення власної оригінальної педагогічної системи.

У 1948 р. Павлиська середня школа являла собою звичайну сільську школу, зруйновану війною. Перед Василем Олександровичем постала ціла низка реальних проблем, серед яких: зруйнована будівля школи, відсутність підручників, методичної літератури, низька успішність, велика кількість другорічників, перенавантаження обов'язковим для засвоєння матеріалом та багато іншого.

Новаторські ідеї педагога-практика щодо навчання, виховання та управління було втілено ним і колективом однодумців у практику роботи Павлишської середньої школи, що протягом 1948 - 1970 рр. стала авторською школою Василя Олександровича Сухомлинського. 


\section{Інноватика у вихованні. Випуск 14. 2021.}

Особливу увагу приділяв Василь Сухомлинський аналізу змісту шкільної освіти. Успішне вирішення цих складних проблем залежить від багатьох чинників. Серед них провідним є суттєве оновлення змісту. 3 одного боку, він має бути осучасненим таким чином, щоб випускники 12річної школи могли швидко адаптуватися у самостійному житті, цілеспрямовано використати свій потенціал як для самореалізації в професійному й особистому плані, так і в інтересах суспільства, держави. А з іншого, - шкільна освіта, зв'язуючи покоління, не може переривати ланцюжок часу, iї покликання, зберігаючи адаптивну роль, виховувати i вчити дітей у контексті викликів нового часу, перенасиченого інформацією.

У Павлиші уроки в початковій школі проводились у зелених класах. Для оптимального планування часу В. Сухомлинський пропонував дітям вранці (до шкільних занять) виконувати домашні завдання, а в другій половині дня читати, грати, займатися улюбленою справою, працювати на свіжому повітрі. Такий розпорядок дня, на переконання педагога, сприяв усебічному розвиткові особистості.

Для учнів початкової школи В. Сухомлинським було створено 300 сторінок «Книги природи»: «Це - 300 спостережень, 300 яскравих картин, що закарбувалися в свідомості дітей» (Сухомлинський, 1977).

Крім грунтовних теоретичних розробок Василем Олександровичем у практику роботи було втілено систему заходів. Найважливішими серед них $\epsilon:$

спеціальні уроки мислення серед природи, розраховані на пробудження, активізацію, яскраве емоційне забарвлення розумових сил;

розв'язування задач на кмітливість;

творчість (складання оповідань і казок);

правильне харчування тощо.

Методи навчання, структура і тип уроку, організаційні й педагогічні елементи, навчальна і виховна мета матеріалу в школі В. Сухомлинського відповідали змісту і завданням розробленої ним педагогічної системи всебічному розвиткові особистості.

Велику увагу педагог звертав на зв'язок дитини з природою. «Хотілося б, щоб у програмах з природознавства i, звичайно, у навчальновиховній роботі вчителя чіткіше виступали дві взаємопов'язані думки: ми живемо в такий час, коли природні ресурси перестали бути практично невичерпними. Під час екскурсій, взагалі під час кожної зустрічі дітей з природою ми намагаємося показати їм світ таким, щоб вони задумались над тією істиною, що природа - це наш дім, і якщо ми будемо безтурботними марнотратцями, ми зруйнуємо його; природа - частинка нас самих, а байдужість до природи - це байдужість до власної долі» (Сухомлинський, 1977).

У Павлиській школі - «Школі під відкритим небом», діють варіації пізнавально-виховного середовища як дослідники, i це таємниче максимально психологічно мобілізує їхнє пізнання світу. «Ми йдемо до 


\section{Інноватика у вихованні. Випуск 14. 2021.}

лісу, сідаємо під дубом - і починається подорож по далеких країнах, у минуле народу, в світ невідомого. Подорожі в невідоме - це моя улюблена справа. Я глибоко переконаний, романтична обстановка, бесіда 3 дітьми серед природи про те, що їх цікавить, - це вогник, що запалює в середовищі дитини любов до знань» (Сухомлинський, 1977). Для педагога важливим було не «вбити» в дитині невгасиму жагу до знань, прагнення до пізнання. Тому головна мета всієї педагогічної діяльності великого педагога полягала у тому, щоб відкрити дитині світ «в живих фарбах, яскравих звуках, у казках і грі, у власній творчості». Засобом для цього були своєрідні «подорожі до витоків мислення і мови», де діти спостерігали за явищами навколишнього світу, слухали вчителя і одночасно малювали в альбомах ті образи, які вони побачили: туман, що огорнув землю як в підводному царстві; сонце - коваль-велетень, що грає на своїй золотій ковалді... і коли у школярів з'являлися питання, це означало, що вони починають думати образами, у них з'являються зустрічні питанняздивування: що робить коваль-велетень вночі? Куди поділися срібні іскорки? Навіщо сонцю кожен день новий вінок? Звідки беруться хмари? Чому бувають блискавка і грім? Що таке веселка? Чому в лісі лунає ехо? Дитяча допитливість «Школи під блакитним небом» розвивалася на основі гуманістичної ідеї: дитина - за своєю природою - мислитель, талановитий дослідник, відкривач світу. Так звані «Подорожі в природу», які організовували педагоги Павлиської школи, супроводжувалися іграми (наприклад, «Пошук таємничого острова», гра в «робінзонів»), спостереженнями за життям тварин і птахів, які збагачували мова і уява учнів. Зміст освіти в перші роки шкільного життя учнів будувався відповідно до завданням початкової школи - поступово привчати до подолання труднощів не тільки у фізичній, а й в інтелектуальній праці. «Учні читали буквар, писали кружечки, палички і букви, виконували завдання - все це поступово входило в їх багатогранне духовне життя» (Сухомлинський 1977).

3 метою дослідження педагогічної спадщини В. Сухомлинського та готовності педагогів до впровадження його ідей в освітній процес сучасного закладу освіти «під блакитним небом» упродовж травня-серпня 2021 року нами було проведено анонімне опитування педагогів Закарпатської області - слухачів курсів підвищення кваліфікації при Закарпатському інституті післядипломної педагогічної освіти. В анкетуванні взяли участь 273 педагоги, серед яких 40,4 \% працівники закладів дошкільної освіти, 56,9 \%- представники закладів загальної освіти, 2,7 - методисти управлінь (відділів) освіти.

Прикметно, що саме у Закарпатській області було проведено дослідження, оскільки природний потенціал краю дає можливість для реалізації різними засобами поєднання духовного і матеріального життя людини з природою, як вважав В. Сухомлинський. Підтвердженням цьому $\epsilon$ яскраві висловлювання педагога: «Природа - колиска дитячої думки і треба прагнути, щоб кожна дитина пройшла школу дитячого мислення 


\section{Інноватика у вихованні. Випуск 14. 2021.}

серед природи». «...Ми вважали дуже важливим виховним завданням те, щоб наші вихованці, бачачи свою єдність $з$ природою, переживали турботу і тривогу про збереження і примноження природних багатств... Думка про те, що ми, діти природи, повинні бути дбайливими і вдячними, особливо виразна і хвилююча тоді, коли діти бачать плоди землі, замислюються, як треба оберігати джерело, з якого ми п’ємо» (Артемова, 2006).

Розмірковуючи над впровадженням ідей В. Сухомлинського про «Школу під відкритим небом», виявляємо, що значна кількість педагогів (81\%) проводять заняття у відкритому природному просторі Закарпаття, також 15 \% педагогів констатують, що переважають ситуації, де вони використовують природне середовище для урізноманітнення занять i тільки 4 \% не застосовують такі методи у своїй роботі (рис.1).

\section{Чи має місце в освітньому процесі сучасного закладу освіти організація пізнавальної діяльності здобувачів освіти у відкритому природному просторі Закрпаття?}

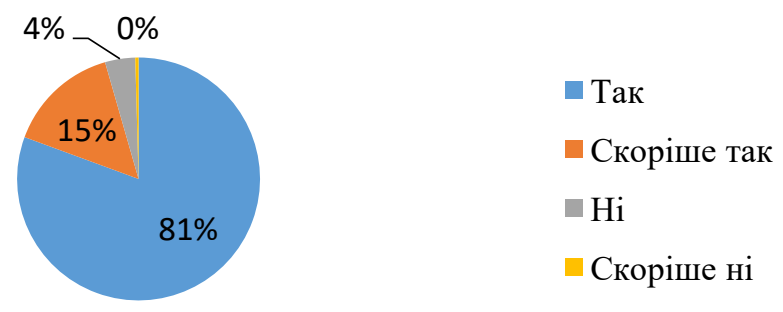

Pис.1. Статистичний розподіл відповідей щзодо організації пізнавальної діяльності здобувачів освіти у відкритому природному просторі Закарпаття

Щодо форм освітньої діяльності, які варто проводити саме «під блакитним небом», думки респондентів розділилися. Більшість схиляється до пошуково-дослідницької діяльності, спостереженнями за явищами живої природи, цільових екскурсій, подорожей, екологічних стежок, квестів. Тільки 131 (20\%) педагог вважає, що можна проводити навчальні заняття у природному середовищі (рис.2). I не дивно, оскільки «...вивести дітей на галявину, зайти з ними до лісу, до парку - справа куди важча, чим провести уроки», - писав В. Сухомлинський.

Василь Олександрович розробив систему уроків мислення, що становлять «заняття серед природи з метою розвитку думки й збагачення мовлення, ... постійного зміцнення й розвитку пам'яті, вироблення гнучкості мислення, швидкості використаних знань, що знаходяться в розумових операціях». Такі уроки проводились у Павлишській середній школі, починаючи з дошкільнят і до завершення восьмого класу. На цих уроках усі діти ставали дослідниками, шукаючи відповіді на безліч питань, 


\section{Інноватика у вихованні. Випуск 14. 2021.}

що постають перед ними, кожен стає талановитим по-своєму. Їх тематика була різноманітна, наприклад:

Що сьогодні стало в полі не таким, як було тиждень тому?

Що ми бачимо навколо себе - в природі - живе і неживе?

Життя у воді, на землі, на деревах.

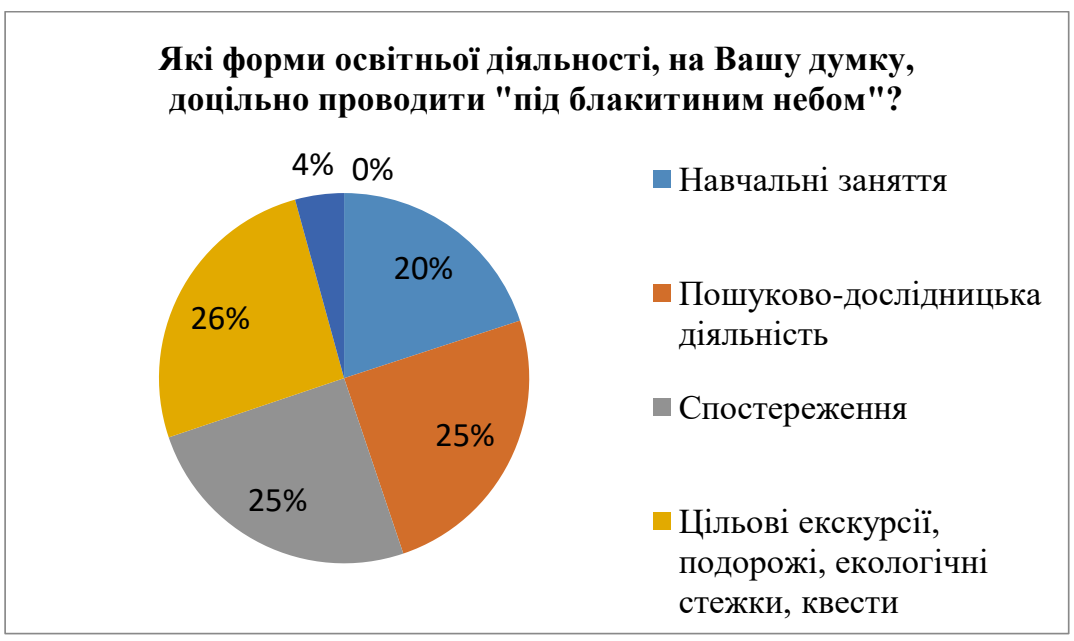

Рис.2. Статистичний розподіл відповідей щодо форм освітньої діяльності «під блакитним небом» (множинний вибір)

Які ж переваги таких занять у природному середовищі? Все залежить від творчого добору педагогом форм, методів, використання прийомів, уміння виробити власну неповторну методику, яка б грунтувалася на індивідуальних вміннях, інтересах й прагненнях, ідеалах вихованців.

Педагоги Закарпаття вважають, що під час інтегрованих занять «під блакитним небом» підвищується інтерес до навчання та дослідження, відбувається зміна видів діяльності, а відтак знімається втома дітей, збагачується життєвий досвід (рис.3).

Василь Сухомлинський сам викладав усі шкільні предмети, тому приділяв велику увагу розробці системи форм, методів і прийомів їх викладання. Наприклад, на уроках історії застосовувались історичні читання для молодших школярів, розраховані на ідейно-емоційний вплив, цикли вечорів, бесід, лекції; у навчанні мови в початкових класах враховувався тривалий характер, поступовість усвідомлення граматичних правил; на уроках граматики відбувалось пояснення фактів і явищ живої мови в процесі самостійного виконання вправ, застосовувались творчі письмові роботи (упродовж 20-ти років склалася традиція тематики творів про природу і працю); при вивченні предметів природничого циклу важливим було проведення аналізу результатів спостережень. 


\section{Які переваги інтегрованих занять «під блакитним небом»?}

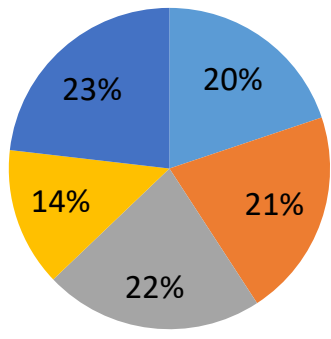

- Підвищується інтерес до навчання та дослідження

- Відбувається зміна видів діяльності

Зняття перевтоми дітей

Рис.3. Статистичний розподіл відповідей щุодо переваг інтегрованих занять «під блакитним небом»

В умовах змін, які відбуваються сьогодні, в освіті розширюються функції та можливості вчителя, з'являються нові соціально-професійні ролі педагога в освітньому процесі. У Концепції Нової української школи зазначено, що сучасний вчитель - це агент змін, тьютор, фасилітатор, модератор, коуч, ментор (Концепція Нової української школи).

Для того, аби опанувати всі ці нові ролі, та відповідати запитам учасників освітнього процесу, вчитель постійно повинен займатися самовдосконаленням, саморозвитком. Учитель - це постійний учень. Він оволодіває новими методиками, новітніми технологіями навчання й вибудовує свою власну професійну траєкторію. Тож робимо висновок, що саме від професіоналізму педагога залежить успіх проведених занять. Яка професійна роль педагога повинна бути пріоритетною на заняттях «під блакитиним небом»?

Під час освітнього процесу ми виконуємо ті чи інші ролі, часто не замислюючись над їхньою сутністю. Педагоги Закарпаття вважають, проводячи заняття у природному середовищі, вони частіше виступають у ролі фасилітатора (30 \%), модератора (27\%) і коуча (24\%) (рис.4.). I це не випадково, оскільки модератор - наставник, організатор групової роботи, що активізує і регламентує процес взаємодії учасників групи на основі демократичних принципів, забезпечує ділове спілкування. Завдання ж учителя-фасилітатора полягає в організації спілкування всіх учасників обговорення 3 нейтральної сторони, налагодження ефективного обміну думками таким чином, щоб зіткнення думок перейшло в конструктивне русло, розбіжності були успішно подолані і прийнятне рішення було вироблено. А коуч допомагає знайти відповіді на власні запитання здобувачів освіти, відпрацьовує до автоматизму різні життєві та професійні ситуації. Отже, варто вести мову про нові соціально-професійні ролі учителя - не як єдиного наставника та джерело знань, а як модератора, 


\section{Інноватика у вихованні. Випуск 14. 2021.}

фасилітатора, коуча, тьютора, супервізора, ментора в індивідуальній освітній траєкторії дитини.

Яка професійна роль педагога повинна бути пріоритетною на заняттях "під блакитиним небом"?

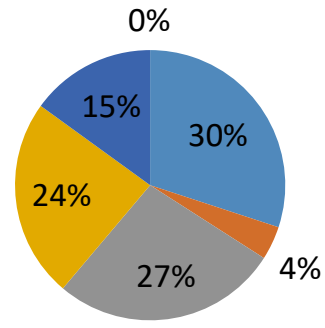

Фасилітатора

- Тьютора

- Модератора

поуча

- Супервізора

Ваш варіант

Рис.4. Статистичний розподіл відповідей щңодо професійної ролі педагога, яка повинна бути пріоритетною на заняттях «під блакитним небом»

Нові ролі педагога реалізуються і в зміні знаннєвої парадигми на компетентнісну. У сучасній школі відбувається криза знаннєвої парадигми, яка обумовлена декількома причинами: зміна самого феномену знання і його співвідношення із суспільною практикою (у цих умовах, як не парадоксально, навчання, побудоване на засвоєнні знань, втрачає сенс); відпадає необхідність перевантажувати пам'ять дитини істинами «про запас», бо існують сховища інформації іншої природи, потрібно тільки навчити учнів правильно користуватися ними і вміти застосовувати знання та інформацію. Зміна парадигми сучасної освіти зі знаннєвої на компетентнісну вимагає оволодіння раціональними прийомами розумової діяльності, формування інтелектуальних умінь, що можливо за умов, якщо до змісту інтелектуального сприйняття увійдуть проблеми і задачі практичного характеру, які потребують самостійного мислення з боку учнів. Все це можна здійснити у процесі застосування активних форм $\mathrm{i}$ методів навчання, тому перед учителем постають нові задачі, виконання нових ролей.

Тому вчителю, у своїй діяльності потрібно переосмислити власну позицію щодо освітнього процесу, оновити професійне мислення, зосередити свою увагу на самоосвіті, систематичному аналізі власної педагогічної діяльності, відстеженні результативності своєї роботи через систему моніторингу. Новий учитель має навчити дітей активності, навикам співпраці в команді, коли учні можуть доповнювати один одного, стимулювати до саморозвитку та самовдосконалення. Коли всі учні $\epsilon$ складовою одного цілісного організму - класу.

«Погляди великого метра педагогіки щодо творчого пошуку вчителя не втратили новаторства донині, сто років поспіль учителі відкривають для 


\section{Інноватика у вихованні. Випуск 14. 2021.}

себе нові вектори професійного доробку Василя Сухомлинського, які слугують для них алгоритмом творчості, самореалізації та самовдосконалення на всіх рівнях...» (Марусинець, Макаренко, 2019).

Що ж впливає на удосконалення професіоналізму вчителя? На думку В. Сухомлинського, це, насамперед, наявність у нього віри в дитину; поєднання емоційної культури 3 тактом; дотримання вчителем інтелектуальної культури; орієнтація учнів на особистий приклад вчителя; поглиблення, поповнення, удосконалення знань; самоаналіз педагогічної праці; іiі дослідницький, творчий характер, використання передового педагогічного досвіду; атмосфера багатого духовного життя колективу. Визначний теоретик і практик доводив, що багатогранність і неповторність педагогічних ситуацій вимагає від сучасного вчителя вміння самостійно переосмислювати теоретичні знання, вміння перекладати їх на мову практичних дій, знаходити більш ефективні засоби вирішення педагогічних завдань. Педагоги Закарпаття також зазначають у своїх відповідях фактори удосконалення професіоналізму вчителя, на які вказував В. Сухомлинський, надаючи перевагу складнику «наявність віри в дитину» (рис.5).

\section{Що впливає на удосконалення професіоналізму педагога (оберіть найбільш важливий показник, опираючись на педагогічну спадщину В.Сухомлинського)?}

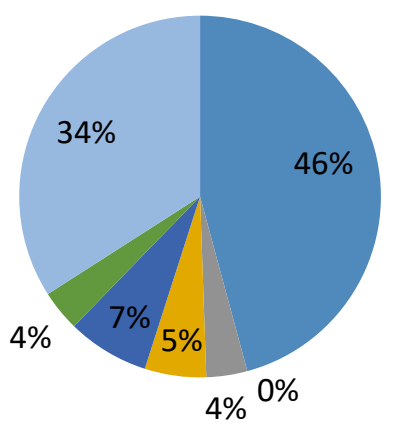

Наявність віри в дитину

- Поєднання емоційної культури з тактом

— Дотримання педагогом інтелектуальної культури

Орієнтація вихованців на особистий приклад педагога

Рис.5. Статистичний розподіл відповідей щодо удосконалення професіоналізму педагога

Вчений був переконаний в тому, що жодна професія не потребує такого творчого напруження, як педагогічна. Він писав: «Я знаю працівників багатьох спеціальностей, але немає - я в цьому впевнений людей більш допитливих, невгамовних, більш одержимих думками про творчість, як учителі... Радість творчої праці, повнота життя завдяки творчості - до цього прагне кожна культурна, освічена людина» (Сухомлинський, 1976-1977, с.119). Саме ці міркування вченого, які стали керівництвом для дії кожного творчого педагога, викладені у 


\section{Інноватика у вихованні. Випуск 14. 2021.}

праці «Сто порад учителю». Вони є основою і сенсом професії вчителя. «Як і всяка кваліфікована, систематична, планомірна праця, виховання та навчання людини $\epsilon$ професією, спеціальністю. Педагогічна професія особлива, специфічна, іiі не можна порівнювати з іншими професіями. Адже вчитель має справу з найдорожчим, що $є$ в житті, - 3 людиною. I саме від мудрості, майстерності, мистецтва й творчості залежить його здоров'я, розум, характер тощо» (Сухомлинський, 1988).

3 метою виявлення творчого підходу до використання авторської педагогічної системи В. Сухомлинського та іiі реалізації в освітньому процесі природного середовища Закарпаття нами було запропоновано педагогам сформулювати тему екологічного проєкту, який міг би бути реалізований у природному просторі нашого краю. Варто акцентувати на деяких з тем, які педагоги вважають реальними для дослідження: «Збережи природу Закарпаття», «Природа - це я!», «Сортування сміття», «Екологічна стежина», «Чиста річка», «Радісний ліс», «Чисте довкілля», «Калейдоскоп екологічних ідей», «Червона книга. Рослини Закарпаття», «Долина нарцисів», «Чисте місто», «Книга скарг і пропозицій», «Цінуємо і бережемо планету Земля», «Високогір'я Закарпаття», «Я і природа», «Природа Карпат», «Мінеральні джерела Закарпаття», «Збережемо природу - джерело життя», «Ознайомлення з екзотичними тваринами (карпатські буйволи)», «Здоров’я нашої природи», «Карпатські дива: вишоватські водоспади, гірське озеро Синевир, Ужанський національний природний парк ...», «Збережи ліси Закарпаття», «Зелена країна», «Дерева - наші друзі», «Природа рідного краю та ії збереження», «Люби і знай, свій рідний край», «Ми - друзі природі»...

Створення подібних проєктів є одним зі шляхів реалізації авторської педагогічної системи Василя Сухомлинського у процесі освітньої діяльності «під блакитним небом». А краса величних Карпат з великими схилами і гострими шапками гір, кришталева прозорість дзвінких річок i срібне звучання чистого повітря Закарпаття спонукає до проведення занять «під блакитним небом».

Висновки і перспективи подальших розвідок. Вважаємо, що педагогічна спадщина В. Сухомлинського в наш час має велике і неоціненне значення. Ї̈̈ використання $є$ доцільним сьогодні, оскільки вона сприяе інтелектуальному, духовному i фізичному розвитку дитини, допомагає виховувати духовне багатство, вчить відчувати, сприймати, аналізувати, порівнювати, має потужні ресурси для підвищення ефективності сучасної екологічної освіти у контексті сучасних вимог.

\section{СПИСОК ВИКОРИСТАНИХ ДЖЕРЕЛ}

Литвин, М. (2013). Використання педагогічної спадщини В.О. Сухомлинського при викладанні природничих дисииплін. Педагогічні ідеї В.О. Сухомлинського: практичне впровадження викладання предметів природничо-математичного напряму: метод. посіб. [Упоряд. Л. Хлань, С. Литвин, Л. Ткаченко, Т. Ціперко]. Кіровоград. Вид-во КОІППО імені Василя Сухомлинського. С. 29-36. 


\section{Інноватика у вихованні. Випуск 14. 2021.}

Сухомлинський, В. (1988). Моя педагогічна система: [3 неопублікованої книги «Педагогічна культура»]. Радянська школа. № 6. С. 87-91; № 7. С.79-84; № 8. С.87-91; № 9. С.86-91.

Сухомлинський, В. (1977). Вибрані твори в n’яти томах. Т.4.К. «Рад. шк.». $638 \mathrm{c.}$

Артемова, Л. (2006). Історія педагогіки Украӥни [Текст]: Підруч. для студ. вищ. пед. навч. закл. / Ред. Л.Л.Сісіна. К. Либідь. 424 с.

Концепиія Нової української школи. Режим доступу: https://osvita.ua/doc/files/news/520/52062/new-school.pdf [Дата звернення 21.06.2021]

Марусинець, М., Макаренко, Л. (2019). Василь Сухомлинський і розвиток професійного акме вчителя. Науковий часопис Національного педагогічного університету імені М. П. Драгоманова Серія 5. Педагогічні науки: реалії та перспективи. Випуск 69 : збірник наукових праць / М-во освіти і науки України, Нац. пед. ун-т імені М. П. Драгоманова. Київ : Вид-во НПУ імені M. П. Драгоманова. С.308 Режим доступу: http://enpuir.npu.edu.ua/bitstream/handle/123456789/28215/Marusinets.pdf?sequence= 1\&isAllowed=y_[Дата звернення 09.08.2021]

Сухомлинський, В. (1976-1977). Проблеми виховання всебічного розвиненої особистості. Вибрані твори : в 5 т. / редкол.: О. Г. Дзеверін (голова) та ін. Київ. Радянська школа. Том 4. С. 372.

Сухомлинський, В. (1988). Сто порад учителеві. Київ. Радянська школа

\section{REFERENCES}

Lytvyn, M. (2013). Vykorystannia pedahohichnoi spadshchyny V.O. Sukhomlynskoho pry vykladanni pryrodnychykh dystsyplin. [The use of V.O. Sukhomlinskyi's pedagogical heritage in teaching natural sciences] Pedahohichni idei V.O. Sukhomlynskoho : praktychne vprovadzhennia vykladannia predmetiv pryrodnycho-matematychnoho napriamu: metod. posib. / [Uporiad. L. Khlan, S. Lytvyn, L. Tkachenko, T. Tsiperko]. Kirovohrad Vyd-vo KOIPPO imeni Vasylia Sukhomlynskoho. S. 29-36. [in Ukrainian].

Sukhomlynskyi, V. (1988). Moia pedahohichna systema: [My pedagogical system] [Z neopublikovanoi knyhy "Pedahohichna kultura"]. Radianska shkola. No 6. S. 87-91; No 7. S.79-84; No 8. S.87-91; No 9. S.86-91. [in Ukrainian].

Sukhomlynskyi, V. (1977). Vybrani tvory v piaty tomakh. [Selected works in five volumes] T.4.K. «Rad shk.». 638 s. [in Ukrainian].

Artemova, L. (2006). Istoriia pedahohiky Ukrainy [Tekst]: Pidruch. dlia stud. vyshch. ped. navch. zakl. / Red. L.L.Sisina. K.: Lybid. 424 s. [in Ukrainian].

Kontseptsiia Novoi ukrainskoi shkoly. [The concept of the New Ukrainian School] Rezhym dostupu: https://osvita.ua/doc/files/news/520/52062/new-school.pdf [Data zvernennia 21.06.2021] [in Ukrainian].

Marusynets, M.M., Makarenko, L.L. (2019). Vasyl Sukhomlynskyi i rozvytok profesiinoho akme vchytelia. [Vasyl Sukhomlynsky and the development of a professional acme teacher] Naukovyi chasopys Natsionalnoho pedahohichnoho universytetu imeni M. P. Drahomanova Seriia 5. Pedahohichni nauky: realii ta perspektyvy. Vypusk 69 : zbirnyk naukovykh prats / M-vo osvity i nauky Ukrainy, Nats. ped. un-t imeni M. P. Drahomanova. Kyiv. Vyd-vo NPU imeni M. P. Drahomanova. S.308

URL: http://enpuir.npu.edu.ua/bitstream/handle/123456789/28215/Marusinets.pdf?sequence= 1\&isAllowed=y [Data zvernennia 09.08.2021] [in Ukrainian]. 
Sukhomlynskyi, V. (1976-1977). Problemy vykhovannia vsebichnoho rozvynenoi osobystosti [Problems of education of the comprehensively developed personality]. Vybrani tvory : v 5 t. / redkol. : O. H. Dzeverin (holova) ta in. Kyiv : Radianska shkola. Tom 4. S. 372. [in Ukrainian].

Sukhomlynskyi, V. (1988). Sto porad uchytelevi. [One hundred tips for teachers]. Kyiv. Radianska shkola. [in Ukrainian].

\title{
IMPLEMENTATION OF THE AUTHOR'S PEDAGOGICAL SYSTEM OF V. SUKHOMLYNSKY INTO THE EDUCATIONAL PROCESS OF THE NATURAL ENVIRONMENT OF ZAKARPATTIA
}

\author{
Tetiana Palko \\ Candidate of Psychological Science, Assistant Professor \\ at the of Department of Pedagogy and Psychology of \\ Zakarpattia Institute of Postgraduate Pedagogical Education, \\ Uzhhorod, Ukraine \\ ORCID: 0000-0003-2273-1472 \\ e-mail: tanya0106.1967@ukr.net
}

Abstract. The article presents a study of the author's pedagogical system of V. Sukhomlynsky, describes the forms of educational activity «under the blue sky». Factors for improving the professionalism of a teacher are outlined, which, according to V. Sukhomlynsky, reveal the creative potential of a teacher and determine the meaning of his professionalism throughout life: belief in child; combination of emotional culture with tact; following intellectual culture; students' orientation to the teacher's personal example; deepening, replenishment, and improvement of knowledge; self-analysis of pedagogical work and its research, and creative nature; the use of advanced pedagogical experience; atmosphere of rich spiritual life of the team.

The great educator proved that nature itself does not educate, only the active interaction between nature and a child educates. Therefore, environmental education and environmental culture are closely connected with environmental activities. V. Sukhomlynskyi believes that, if the most ecological knowledge of environmental protection is not implemented in practice it will be not enough. It is important that students participate in the preservation and enrichment of the nature of the native land, only in this case they develop the necessary skills and abilities, develop a responsible, caring attitude to the environment. In order to study the pedagogical heritage of V. Sukhomlynskyi and the readiness of teachers to implement his ideas in the educational process of a modern educational institution "under the blue sky" during May-August 2021 we conducted an anonymous survey of teachers of Zakarpattia region - participants of advanced training courses education. It is noteworthy that it was in the Zakarpattia region that the study was conducted, as the natural potential of the region allows for the realization of various means of combining the spiritual and material life of a man with nature, according to V. Sukhomlinsky.

Keywords: author's pedagogical system, "School under the blue sky", Pavlysh school, facilitator, moderator, coach.

Стаття надійшла до редакиії 01.09.2021p. 